Article

\title{
The Impact of Corporate Governance on the Financial Performance of the Banking Sector in the MENA (Middle Eastern and North African) Region: An Immunity Test of Banks for COVID-19
}

\author{
Hani El-Chaarani ${ }^{1}$ (D), Rebecca Abraham ${ }^{2, *(D)}$ and Yahya Skaf ${ }^{3}$ (D) \\ 1 College of Business Administration, Beirut Arab University, P.O. Box 1150-20, Riad El Solh 11072809, Lebanon; \\ h.shaarani@bau.edu.lb \\ 2 Huizenga College of Business, Nova Southeastern University, 3301 College Avenue, \\ Fort Lauderdale, FL 33314, USA \\ 3 Rafic Hariri University Campus-Hadath, Lebanese University, P.O. Box 6573/14, Beirut 11072809, Lebanon; \\ yahya.skaf@ul.edu.lb \\ * Correspondence: abraham@nova.edu
}

Citation: El-Chaarani, Hani, Rebecca Abraham, and Yahya Skaf. 2022. The Impact of Corporate Governance on the Financial Performance of the Banking Sector in the MENA (Middle Eastern and North African) Region: An Immunity Test of Banks for COVID-19. Journal of Risk and Financial Management 15: 82. https://doi.org/10.3390/ jrfm15020082

Academic Editor: Ştefan

Cristian Gherghina

Received: 21 December 2021

Accepted: 11 February 2022

Published: 16 February 2022

Publisher's Note: MDPI stays neutral with regard to jurisdictional claims in published maps and institutional affiliations.

Copyright: (C) 2022 by the authors. Licensee MDPI, Basel, Switzerland. This article is an open access article distributed under the terms and conditions of the Creative Commons Attribution (CC BY) license (https:// creativecommons.org/licenses/by/ $4.0 /)$.

\begin{abstract}
The purpose of this paper is to measure the impact of internal and external corporate governance mechanisms on the financial performance of banks in the under-researched Middle Eastern and North African (MENA) region during the COVID-19 pandemic period. Bank annual reports, the Orbis Bank Focus database, and World Bank reports were used to collect both financial and non-financial information on the banking sector, followed by fixed effects regressions and two-stage least squares. Results showed that the corporate governance measures of presence of independent members on the board of directors, high ownership concentration, lack of political pressure on board members, and strong legal protection, had positive effects on bank financial performance. Corporate governance mechanisms, such as performance-based compensation, the presence of women on boards, moderate size of the board, and anti-takeover mechanisms had no significant impact on bank performance during the crisis period. An effective internal and external corporate governance mechanism could improve the financial performance of banks in MENA countries in times of pandemics and crises.
\end{abstract}

Keywords: corporate governance; bank performance; COVID-19; Middle East and North Africa

\section{Introduction}

The COVID-19 pandemic originated in China at the end of 2019, spreading globally, thereafter. Governments in both developed and developing countries implemented strict protocols and lockdown restrictions to minimize the virus's impact. Unlike typical economic downturns, disruptions of social activity ensued. Schools, colleges, and offices closed, sending their occupants to their homes. With the exception of suppliers of essentials, such as food, and medicines, in person retail selling, along with life events such as weddings, and travel, ceased. Online sales and online communication, such as Zoom meetings surged. In other words, there was widespread disruption in economic activity across sectors (Koutoupis et al. 2021).

During crises, bank liquidity falls. Depositors withdraw savings to cope with economic uncertainty when they do not receive any financial support by local government (Goodell 2020; Kozak 2021). Defaults on most loans, including mortgages, automobile loans, and personal loans, further reduce bank liquidity. As depository institutions, with considerable dependence on loan interest income, banks are particularly vulnerable to the economic disruption of a pandemic (Goodell 2020; Sivaprasad and Mathew 2021). Could banks cope with this disruption? Only if they have transparency about losses in loan 
income, rising default rates, deficits in net income, and reductions in retained earnings, respectively, followed by corrective actions authorized by the board, and implemented by management. Given the loss of revenue from defaults on loans, and deposit drains of savings, management must find innovative ways of reducing cash outflows and increasing cash inflows. Strategies may include suspending loan commitments, changing lending rates and liquidating securities, to preserve capital. Investing in derivatives, or offering standby letters of credit, may generate fee income. Offering additional services through online banking, such as credit cards with reduced rates, may attract new customers engaged in online purchasing. Management may be incentivized to adopt these measures if the board has governance mechanisms that encourage innovative thinking, such as having independent directors, preventing CEO-board chair duality, implementing performance-based compensation, and limiting board size. These measures may encourage the board to reward creative methods to increase bank profitability, while curbing excessive risk-taking. Accordingly, this manuscript examines how corporate governance influenced bank performance during the COVID-19 pandemic.

We employed a unique sample of banks located in the Middle East and North Africa. Banks in this region accumulate cash hoards in the oil-rich countries of the Middle East, while facing liquidity problems in the less-developed agrarian economies of North Africa. Trade with former colonial powers is financed by banks, with longstanding relationships with European counterparts that facilitate the use of letters of credit, bankers' acceptances, and loan commitments. The pandemic reduced the demand for oil, and in turn, the cash balances of oil exporters, imposing liquidity challenges on banks. Curtailment of trade stalled the flow of letters of credit, bankers' acceptances, and loan commitments. It is worthwhile to examine the impact of the COVID-19 pandemic on bank profitability in this region to observe the financial impact on banks of disruptions to the oil trade, commodity trade, and retail trade, as banks are the chief facilitators of such trade.

The basic role of corporate governance lies in regulating the board's actions. It is a control and monitoring system in which the board of directors oversees the work of management to maximize shareholder value (Jebran and Chen 2020). Corporate governance is one of the most important dimensions of ESG (environmental, social and governance) indices revealing its capacity to ensure legitimacy (Brammer and Pavelin 2008), trust (Akhtaruzzaman et al. 2021) and the reputation of banking firms during crisis (Buallay 2019; Miralles-Quirós et al. 2019).

Studies on internal and external corporate governance mechanisms' role in maintaining bank performance during the pandemic are still very rare (Khatib and Nour 2021). A few restrictions on effective corporate governance have been noted, including the excessive presence of management on the board of directors, lack of women on the board, excessively large or small boards, and boards that failed to impartially evaluate top management (see El-Chaarani 2015 for a review). There is a paucity of literature on the impact of these corporate governance mechanisms on banks, particularly in the MENA region, during the current 2020-2021 COVID-19 pandemic. This manuscript attempts to close this research gap by addressing the following research question:

What is the impact of corporate governance mechanisms on the financial performance of banks during the COVID-19 pandemic period in the MENA region?

We contribute to the literature in distinctive ways. First, this study is one of the few papers to assess the impact of corporate governance on bank performance during a pandemic, i.e., the spread of the COVID-19 virus. Second, this research adds to the literature on the governance structures of the banking sector in the MENA region. Third, the empirical results of this research could be used by bankers, financial regulators, and governments to review the corporate structure of the banking industry in the MENA region, as well as devising appropriate structures which lead to mitigation of the adverse economic impacts of COVID-19. 


\section{Literature Review}

\subsection{Theoretical Background}

Property Rights Theory: Property rights theory, developed by Alchian and Demsetz (1972), conceives the firm as a union of contracts wherein the manager's responsibility is to choose workers, while defining the scope of the tasks. This theory suggests that ownership and control rights should be given to insiders. Rights over production factors should be allocated to different stakeholders on the basis that the income from providing rights exceeds the costs. Subsequently, Jensen and Meckling (1976) introduced agency theory. Agency theory has its roots in property rights theory's view of the firm as a nexus of contracts. Managers are agents of shareholders (owners), who are expected to act in the best interest of the shareholders. Yet, managers often act to further their own interests at the expense of the shareholders (Daily et al. 2003). An example would be excessive spending on perks, which reduces the net income of the firm (Kaur et al. 2021). The proposed solution to such conflicts lies in an appropriate design of agents' incentives to reduce moral hazards and agency loss. Rewards for superior stock returns, higher economic value added, and increasing liquidity, could be used to motivate management to pursue shareholder interests.

Entrenchment Theory: Entrenchment theory, is an extreme form of agency theory. Managers benefit from information asymmetry by making investment decisions that make them irreplaceable and entrenched in their positions (Hodgson 2015). Given their knowledge of the financial status of the firm, they would know about underutilized sources of cash, such as funding for defunct projects, or canceled insurance policies. These sources of cash can form expense accounts or be used to fund golden parachutes. Other notable entrenchment practices include poison pills (preventing dilution of ownership by offering additional shares to existing shareholders), and supermajority amendments (requiring management's vote to approve key measures). Internal mechanisms to control entrenchment include performance-based compensation, board of directors' independence, and ownership concentration, whereas external mechanisms could include legal protection (Jensen and Meckling 1976).

Resource Dependency Theory: This theory suggests that a firm is an open system that should acquire external resources from other organizations. Since external resources can be scarce or controlled, inequality can arise in terms of power and access to external resources. To avoid such outcomes, the theory argues that departments which lack access to external resources should develop strategies and internal structures to enhance their bargaining power (Davis and Cobb 2010). As an example, one department may have links to external consultants, who are experts in their field. Another department in the organization may not have such connections, placing it at a disadvantage. The latter may forge such linkages, or demand representation on key committees, or other decision-making bodies.

Stakeholder Theory: The main objective of the other theories is to maximize the wealth of the shareholders. Freeman (1984) introduced stakeholder theory that goes beyond the sole objective of satisfying the shareholders. In this theory, the company is socially responsible towards all of the parties who can affect or can be affected by the firms' activities. Mitchell et al. (1997) proposed three attributes to identify the firm's stakeholders: power, legitimacy, and/or urgency. Shareholders, key vendors, and unions have power. Workers, through their employment contracts with the firm, have legitimacy. Environmental groups who seek restrictions on the firm's activities have urgency. Compared to the other theories, the stakeholder approach achieves competitive advantage throughout by satisfying the different stakeholders (European Commission 2008). In the case of the banking industry, stakeholder theory consists of satisfying depositors, owners, and other relevant stakeholders based on an effective governance structure that enhances trust and transparency (Vicnente-Ramos et al. 2020).

Stewardship Theory: Finally, stewardship theory suggests that owners' interests are aligned with those of managers, as managers are stewards of the firm. Managers are expected to elevate performance to provide higher returns, as they are imbued with the desire to safeguard the interest of the shareholders and ensure the firm's continued 
prosperity (Davis et al. 1997). Stewardship governance requires transparent and truthful communication between managers and owners.

The theoretical framework of this research paper is rooted in the combination of different theories mentioned above since they are highly intercorrelated. In the case of banking firms, different types of conflict exist between different parties due to the separation between ownership and control (property rights theory). To ensure efficient leadership, the owners of banks hire external and professional CEOs that could use the information asymmetry to entrench themselves and increase their private benefits (entrenchment theory). To avoid such results, the owners must design an efficient corporate governance system by employing external and independent experts (resource dependency theory) to satisfy the relevant parties implied in banking activities, such as depositors and debtholders (stakeholder theory). Once they are well controlled and motivated, CEOs of banks are expected to communicate and cooperate with different stakeholders to provide higher performance.

\subsection{The Impact of Corporate Governance on Bank Performance during the COVID-19 Period}

Scholars have investigated the role of corporate governance in mitigating the negative impact of the pandemic on banks, primarily in developed countries. Opposing findings have emerged. One group of studies have found that corporate governance mechanisms yielded a positive impact on bank performance, while another group of studies supported the contrary.

A case study conducted on an international bank also revealed that effective corporate governance mechanisms contributed to better crisis management (Sivaprasad and Mathew 2021). Effective corporate governance mechanisms were based on objective evaluations of management performance. They included a well-structured board of directors, a high level of transparency, together with independent and professional internal committees which enhanced trust toward the bank. Studies of non-bank corporations supported the benefit of board objectivity with Broadstock et al. (2021) finding that firms with these governance mechanisms witnessed a decrease in their credit risk. Scherer and Voegtlin (2020) found that these governance mechanisms stimulated firms to innovate, resulting in enhanced financial performance. Certain boards had effective communication with the external environment during crises due to their capacity to improve trust and send positive signals to depositors and other relevant stakeholders (Song et al. 2020). Khatib and Nour (2021) suggested that a larger board of directors can bring diverse experience, better oversight mechanisms, and more effective communication during crisis periods.

On the other hand, other studies did not reveal any significant and direct impact of corporate governance structure and attributes on the performance of the banking industry during the pandemic period. Demir and Danisman (2021) conducted a study during the first four months of 2020 on 1927 banks from 110 countries, finding that governance scores did not have a significant influence on bank returns during the COVID-19 outbreak. These results are consistent with the observed results of Takahashi and Yamada (2021) who studied the impact of different factors on Japanese stock returns during the COVID-19 pandemic. Along similar lines, other studies have found that board independence was not an important performance determinant of bank performance during the pandemic period (Amore et al. 2020).

\subsection{Hypotheses Development}

\subsubsection{Independent Members on the Board of Directors}

An independent director does not have a material interest in the bank, other than sitting fees. As such, these individuals cannot hold senior management positions, suggesting that they would be impartial in their assessment of management's performance. Accordingly, the Basel Committee (2015), which establishes international standards for bank regulation, recommended that the board of directors should be professional and independent to manage bank risk and improve bank performance. Unbiased assessments 
of management performance are crucial during a pandemic as the board needs to impartially assess the new strategies being implemented to increase liquidity and replace lost fee income. Independent directors must have the freedom to support effective new strategies, while rejecting ineffective strategies, regardless of opposition from management.

Some empirical support for the positive impact of the presence of independent directors on the board emerges from studies of bank performance in non-pandemic times. In a study of 158 listed banks in nine countries, García-Meca et al. (2015) found that the performance of banks measured by return on assets (ROA), and Tobin's Q was affected positively by the number of independent directors on the board of directors. Another study of 293 banks listed in the Indonesian stock exchange market showed a positive impact of the independent board of directors on bank performance (Handriani and Robiyanto 2019). A study on 207 bankrupted banks found that independent boards were better at searching for information, giving advice, and accessing needed capital (Arora 2018).

Hence, the first hypothesis is,

Hypothesis 1 (H1). The presence of independent members on the board of directors had a positive impact on bank performance during the COVID-19 pandemic period in the MENA region.

\subsubsection{Gender Diversity on the Board of Directors}

Intuitively, the presence of women on the boards of banks brings diverse experiences and diverse backgrounds into decision-making. Pandemic disruptions are once-in-ageneration events. The development of innovative strategies to increase bank liquidity in the wake of falling oil prices, trade disruptions, and declining sales of commodities that form key exports in small, agrarian economies, requires creativity, willingness to experiment, and acceptance of risk. Women with a range of backgrounds and experiences, may be able to draw on their diverse experiences to suggest creative solutions, particularly since many of them have had to employ creative coping strategies to advance professionally in environments that restricted their opportunities. Empirical support for this thesis emerges from diversity specialists, who observed that the presence of women in top managerial positions in non-pandemic periods improved the decision-making process (Westphal and Milton 2000; Hays-Thomas 2004). In banks, women members of the board of directors had a positive impact on bank return on assets (ROA), and return on equity (ROE), in developed countries (García-Meca et al. 2015; Mertzanis et al. 2019).

Therefore, the second hypothesis is as follows:

Hypothesis 2 (H2). The presence of women on the board of directors of banks in the MENA region had a positive impact on bank performance during the COVID-19 pandemic period.

\subsubsection{CEO Duality on the Board of Directors}

CEO duality is another dimension of the board of directors in which a CEO could perform a dual role as chairman of the board. Concern about CEO duality originates from entrenchment theory. CEOs who are entrenched thrive on information asymmetry, which gives them exclusive knowledge of the bank's finances. They may invest in low-return projects, or projects with negative net present value, which direct benefits to close friends and family members. An example would be directing bank loans with high risk of default to businesses owned by these individuals. CEOs, who chair the board, feel confident in making these suboptimal investments, as they can withhold information about these financial transactions from other board members. Given the power of the chairman of the board, other members of the board would be reluctant to raise questions regarding these investments. During crisis periods, such wasteful spending can deplete declining cash flows, exacerbating liquidity problems. CEO duality in the banking industry could lead to a single individual acquiring the authority of multiple positions (e.g., CEO, human resources director, chief financial officer), resulting in the development of lobbying behavior for personally beneficial projects on a continuous basis. Furthermore, CEO duality has been 
identified as a barrier to the objective evaluation of management, mainly in less-developed countries (Abhijith and Wamba 2013).

Based on the above, the third hypothesis is as follows:

Hypothesis 3 (H3). CEO duality had a negative impact on bank performance during the COVID19 pandemic period in the MENA region.

\subsubsection{Large Board Size}

Large sized boards of directors can be a source of declining performance due to coordination and control problems, or increased time consumption in the decision-making process (Pathan and Faff 2012; Bhattrai 2017; Lamichhane 2018). Studies of Nepalese banks may be more relevant than those conducted in developed countries, given that Nepal is a low-income developing country similar to the former French colonies of North Africa. Bhattrai (2017) found evidence of conflict among board members on large boards of Nepalese banks. Similarly, Chenini and Anis (2018) found that bank performance was negatively affected by the presence of a large board of directors. They argued that an oversized board of directors decreased the efficiency of governance mechanisms, and, thus, led to reduced performance of banks. We conjecture that, during a pandemic, when the board needed to be focused and directed on assisting management to reduce spending, and find new revenue sources, an excessively large board may lose direction, due to each person having different goals, and varying in their opinions of corrective measures to be undertaken.

Thus, the next hypothesis is as follows:

Hypothesis 4 (H4). Large board size had a negative impact on bank performance during the COVID-19 pandemic period in the MENA region.

\subsubsection{Concentrated Ownership Structure}

Ownership structure can be analyzed through two different components: concentration level, and type of concentration. The concentration level of ownership is defined by the level of capital owned by the ultimate owners. Ownership type is defined by the identity of owners, either internal managers, or external institutional investors, or foreigners. Ownership concentration level is found to have a positive effect on firm performance because a concentrated ownership structure reduces agency problems between managers and shareholders (Nguyen et al. 2020). The MENA region may have such large shareholders of banks, as bank stock may be an attractive, less risky investment for owners of oil wealth, who are financially capable of acquiring large volumes of bank equity. Agency effects diminish with the presence of a few large shareholders, who own much of the stock. Their power permits them to dictate policy to management, as management wishes to appease influential individuals who could prevail upon the board to terminate them. During crises, such large owners may assume even more power, as there is an increased likelihood of management failing to meet its financial goals, increasing the propensity to terminate managers' contracts, if disaffected owners report them to the board.

In the banking industry, de Haan et al. (2010) showed that concentrated ownership leads banks to avoid excessively risky investments. Adnan et al. (2011) argued that the existence of blockholders enhanced the control of the CEO and mitigated the impact of crisis periods in Malaysia.

Based on the above discussion, the next hypothesis is stated as follows,

Hypothesis 5 (H5). Concentrated ownership level had a positive impact on bank performance during the COVID-19 pandemic period. 


\subsubsection{Ownership Type}

Ownership concentration could be analyzed based on the identity of the owner. Managers who own stock consider themselves to be stewards of the firm. Stewardship theory maintains that managers elevate performance to provide higher returns, as they are imbued with a desire to safeguard the interest of the shareholders, ensuring the firm's continued prosperity (Davis et al. 1997). Fahlenbrach and Stulz (2011), Westman (2011) and Kabigting (2011) studied the relationship between managerial ownership bank profitability. They observed that increased insider ownership led to a better alignment of interests between CEOs and bank performance. Such commitment by management to maintaining the bank's prosperity will keep managers steadfastly focused on their work during financial crises.

Based on the above, the following hypothesis is suggested:

Hypothesis 5a (H5a). Internal ownership concentration had a positive impact on bank performance during the COVID-19 pandemic period.

The active existence of foreign or institutional investors as shareholders plays an important role in maintaining effective governance during crises, outside the MENA region (Jebran and Chen 2020). Outsiders tend to request more information from analysts and experts (Chang et al. 2007). Institutional investors also use their professional expertise of managing their own portfolios in managing the bank's portfolio, resulting in more sophisticated decision-making during crisis periods. Empirically, a positive relationship between bank performance and the presence of both institutional and foreign investors has been found in non-crisis periods (Baek et al. 2004; Anand et al. 2013; Georgantopoulos and Filos 2017). Thus, the next hypothesis is as follows:

Hypothesis $\mathbf{5 b} \mathbf{b} \mathbf{H} \mathbf{5 b})$. External ownership concentration had a positive impact on bank performance during the COVID-19 pandemic period.

\subsubsection{Anti-Takeover Mechanisms}

An underperforming company is subject to undervaluation in the market; consequently, it could become an easy takeover target. In the MENA region, small banks in commodity trade financing may have lacked the capital reserves to mitigate the effects of declining revenue during the pandemic. Eroding liquidity made them takeover targets by large financial institutions with established capital bases to sustain themselves during the downturn. More than $40 \%$ of CEOs were replaced by other executives within five years through the acquisition of firms or takeover (Lehn and Zhao 2006). Therefore, executives who consider acquisitions to be risky for their tenure with the firm, may implement antitakeover mechanisms to avoid the firm's acquisition, or at least to prevent hostile bidders from gaining control (Bebchuk et al. 2009).

Different types of anti-takeover mechanism exist. Some of these defensive devices can make the acquisition more costly for the bidding firm, while other mechanisms increase the legal requirement to approve an acquisition. The takeover defenses can also work on delaying the takeover and thus make the takeover less interesting (Gompers et al. 2003). The most common anti-takeover defenses include golden parachutes, poison pills, staggered boards, and supermajority requirements for mergers (Bebchuk et al. 2002). For example, a golden parachute is an agreement that the $\mathrm{CEO}$ will receive significant compensation in the event of job termination. This mechanism provides the executive with a certain degree of financial security, thereby motivating him or her to work in the best interests of the firm. The poison pill is another tactic aimed at diluting the ownership percentage acquired by the bidder through offering new shares to existing shareholders, making the acquisition more expensive for the acquirer. A staggered board is an anti-takeover technique that consists of splitting members into different classes (commonly three classes). Each class serves for a different length of time. This classification makes it impossible for the bidding firm to gain full board control in a single year, even with majority ownership and, thus, gives 
time for the existing board to deter the takeover. Finally, the supermajority amendment is a defensive mechanism that requires a substantial majority that is usually above $67 \%$ of the voting rights to approve an acquisition. This requirement may curtail the takeover completely.

Empirical findings have shown that anti-takeover mechanisms are used by senior managers to entrench themselves and protect their positions at the top of a firm. In this vein, Al Dah et al. (2017) revealed a negative and significant relationship between firm performance and the existence of anti-takeover provisions, suggesting CEOs used the anti-takeover mechanism to increase their private benefits and ensure their managerial continuity. During a pandemic, such entrenchment of existing management, and their emphasis on self-preservation would distract them from undertaking innovative measures to retain profitability. They may become obsessed with pursuing stable strategies that were effective in normal times but which could erode their financial strengths during a time of crises, such as the retention of ineffective managers who are primarily loyalists, rather than innovators.

Therefore, the next hypothesis is defined as follows:

Hypothesis 6 (H6). The presence of anti-takeover mechanisms had a negative impact on bank performance during the COVID-19 pandemic period.

\subsubsection{Compensation Policy}

A debate on executive and board compensation was stimulated by the global crisis in 2008 (OECD 2017). CEO compensation has captured the attention of different regulators, principle setters, and the media (Lagasio 2018). CEOs who refrained from agency behaviors engaged in moderate risk-taking to find alternative revenue streams during the pandemic. Alternately, those who subscribed to the managerial power theory (Bebchuk and Weisbach 2010) engaged in reckless risk-taking that diminished bank performance. Should compensation be used to curb risk-taking during a pandemic, or encourage it? Since we view experimentation with new financial instruments to be a source of revenue when traditional revenue streams fail during a pandemic, compensation practices that encourage risk-taking to promote shareholder interests, i.e., high stock returns, are likely to be more profitable than risk-aversion.

Therefore, the next hypothesis is structured as follows:

Hypothesis 7 (H7). The presence of a performance-based compensation plan had a positive impact on bank performance during the COVID-19 pandemic period.

\subsubsection{External Corporate Governance Tools}

Two types of external corporate governance mechanisms are considered, namely, investors' legal protection, and the efficiency of governance in public institutions.

Investors' legal protection is considered an external corporate mechanism that aims to protect shareholders from expropriation by executives. The existence of a high level of legal protection is considered an efficient governance tool that could help to control the behavior of CEOs in banks and limit any expropriation behavior by management (El-Chaarani 2015). The contribution of central banks and other financial authorities in ensuring bank stability through the definition of key lending rate and monetary policy could also limit the opportunistic behavior of CEOs and create a favorable investment climate in the banking sector (Ghazali and Musnadi 2017; Brusov et al. 2018; Noreen et al. 2018).

In the case of a low level of legal protection, the agent has more capacity to abuse his or her position to maximize private benefits (Beck et al. 2003; Claessens et al. 2000). A series of studies, including La Porta et al. (2000), Durnev and Kim (2005), and Black et al. (2016), found that a firm's value and performance were positively correlated with the existence of efficient corporate governance, mainly in countries characterized by the existence of a high level of investor protection. They stated that, in situations of strong legal protection, CEOs 
are more disciplined since they must follow the principles of transparency and disclosure. They also showed that weak legal protection is associated with decreased transparency, thereby increasing opportunistic behaviors (Claessens et al. 2000).

In the case of weak legal protection, public institutions could intervene to close the investor protection gap in the regulatory system (Barth et al. 2000; Klapper and Love 2002). Kutan et al. (2017) and Bermpei et al. (2018) showed that effective control executed by public institutions had an important role in protecting depositors and investors against corruption by reinforcing the control process and enhancing the capital structure of banking firms. Accordingly, the last two hypotheses are defined as follows:

Hypothesis $\mathbf{8}$ (H8). The presence of a high level of legal protection had a positive impact on bank performance during the COVID-19 pandemic period.

Hypothesis 9 (H9). The presence of a high level of government oversight had a positive impact on bank performance during the COVID-19 pandemic period.

\section{Materials and Methods}

\subsection{Data Collection and Sample Characteristics}

Bank financial data in the MENA region was collected from the Orbis Bankscope Database. Data pertaining to corporate governance mechanisms were collected from bank annual reports, and Worldwide Governance Indicators. The population consists of all commercial banks operating in the MENA region during 2020. In total, 20 countries belonging to the MENA classification of the World Bank, were considered. Lebanon, Iraq, Djibouti, Algeria, Yemen, Iran, Palestine, Libya, and Syria were deleted due to their banking crisis, political instability, and considerable fiscal deficits. Malta was also excluded since its membership of the European Union causes its banking system to be controlled by European regulators. The total number of banks studied were 148 banks from eleven countries including Qatar, Oman, Bahrain, Saudi Arabia, Egypt, Kuwait, Jordan, Morocco, United Arab Emirates, Tunisia, and Israel. All banks with unavailable financial data and non-financial data related to internal corporate governance mechanisms were excluded. Table 1 shows the distribution of banks per country in the MENA region.

Table 1. The Sample.

\begin{tabular}{ccc}
\hline Country & Number of Banks & $\%$ \\
\hline Qatar & 12 & $7.59 \%$ \\
\hline Oman & 5 & $3.16 \%$ \\
\hline Bahrain & 10 & $6.33 \%$ \\
\hline Saudi Arabia & 10 & $6.33 \%$ \\
\hline Egypt & 25 & $15.82 \%$ \\
\hline Kuwait & 9 & $5.70 \%$ \\
\hline Jordan & 14 & $8.86 \%$ \\
\hline Morocco & 12 & $7.59 \%$ \\
\hline United Arab Emirates & 19 & $12.03 \%$ \\
\hline Tunisia & 20 & $12.66 \%$ \\
\hline Israel & 12 & $7.59 \%$ \\
\hline Iran & 10 & $6.33 \%$ \\
\hline Total & 158 & $100 \%$ \\
\hline
\end{tabular}

\subsection{Methodology}

The objective of this research is to reveal the impact of internal and external corporate governance measures on the performance of the banking sector in the MENA region during the 2019, COVID-19 pandemic period. We identified 2 dependent and 10 independent vari- 
ables, 2 external corporate governance mechanisms, and 8 internal corporate governance devices. All the dependent, independent, and control variables are presented in Table 2 and Figure 1.

Both Tobin's Q (TOBQ) and the credit risk ratio (CRR) were used as proxies to measure the performance of banking firms during the COVID-19 pandemic period. El-Chaarani (2015) stated that Tobin's Q (TOBQ) is one of the most important variables used to detect the impact of corporate governance structure in banking firms.

The credit risk ratio (CRR), reflecting the level of non-performing loans, should not be ignored since it could show the capacity of managerial and corporate governance structure (El-Chaarani 2015; Permatasari 2020) to mitigate the impact of crisis.

The selection of internal corporate governance variables has its basic roots in agency and property rights theories (Alchian and Demsetz 1972; Jensen and Meckling 1976), and several empirical studies (Durnev and Kim 2005; Pathan and Faff 2012; El-Chaarani 2015; Lagasio 2018; Permatasari 2020) that recommended principals (owners) separate different executive positions (CEOD), hire independent members on the board of directors (BIND), lower the level of separation between ownership and control (INTO and EXTO), and define a performance-based compensation plan (COMP) to limit takeover strategy and expropriation of private benefits by CEOs (ANTT).

Table 2. Variable Descriptions.

\begin{tabular}{|c|c|c|c|c|}
\hline Variable Type & Description & Symbol & Formula & Source \\
\hline \multirow[t]{2}{*}{ Dependent } & Bank performance (Tobin's Q) & TOBQ & $\begin{array}{l}\text { (Market value of common stocks }+ \text { book value of } \\
\text { preferred stocks }+ \text { book value of debts) } /\left(\sum \text { assets }\right)\end{array}$ & $\begin{array}{l}\text { El-Chaarani (2015), } \\
\text { García-Meca et al. (2015) }\end{array}$ \\
\hline & Credit Risk & CRR & 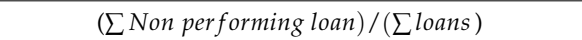 & Permatasari (2020) \\
\hline \multirow{10}{*}{ Independent } & CEO duality & CEOD & $\begin{array}{c}\text { Dichotomous variable that equals } 1 \text { if there is CEO } \\
\text { duality and } 0 \text { otherwise }\end{array}$ & Abhijith and Wamba (2013) \\
\hline & Size of board & BSIZ & Number of members on the board of directors. & $\begin{array}{l}\text { Pathan and Faff (2012), } \\
\text { Bhattrai (2017) }\end{array}$ \\
\hline & Independent members & BIND & $\begin{array}{l}\text { Percentage of independent members on the board of } \\
\text { directors. }\end{array}$ & $\begin{array}{l}\text { García-Meca et al. (2015), } \\
\text { Handriani and Robiyanto (2019) }\end{array}$ \\
\hline & Gender of board member & BWOM & Percentage of women on the board of directors. & $\begin{array}{l}\text { García-Meca et al. (2015), } \\
\text { Mertzanis et al. (2019) }\end{array}$ \\
\hline & $\begin{array}{l}\text { Internal ownership } \\
\text { concentration }\end{array}$ & INTO & $\begin{array}{c}\text { Ownership concentration owned by CEO or } \\
\text { executives }\end{array}$ & $\begin{array}{l}\text { Fahlenbrach and Stulz (2011), } \\
\text { Westman (2011) }\end{array}$ \\
\hline & $\begin{array}{l}\text { External ownership } \\
\text { concentration }\end{array}$ & EXTO & $\begin{array}{l}\text { Ownership concentration owned by institutional or } \\
\text { foreign investors. }\end{array}$ & $\begin{array}{l}\text { Baek et al. (2004), } \\
\text { Anand et al. (2013) }\end{array}$ \\
\hline & Anti-takeover mechanisms & ANTT & $\begin{array}{l}\text { Number of anti-takeover tools used by CEO or bank } \\
\text { owners (ANTT), such as dual voting rights, limited } \\
\text { voting rights, poison pills, golden parachutes, } \\
\text { supermajority voting rights, cumulative voting, } \\
\text { pyramid structures, cross ownership participation, } \\
\text { restrictions on removal of executives, provision for } \\
\text { fair price, confidential policies for voting rights and } \\
\text { advanced notification for owners' proposals. }\end{array}$ & Al Dah et al. (2017) \\
\hline & Compensation & COMP & $\begin{array}{c}\text { Dichotomous variable that equals } 1 \text { if the bank has a } \\
\text { performance-based compensation plan and } 0 \\
\text { otherwise. }\end{array}$ & Lagasio (2018) \\
\hline & Legal protection indicator & LEGP & $\begin{array}{l}\text { Provided by Worldwide Governance Indicators, this } \\
\text { indicator measures the capacity to establish new } \\
\text { financial regulation by regulatory authorities. }\end{array}$ & $\begin{array}{l}\text { Durnev and Kim (2005), } \\
\text { Black et al. (2016) }\end{array}$ \\
\hline & $\begin{array}{l}\text { Government effectiveness } \\
\text { indicator }\end{array}$ & GOVE & $\begin{array}{l}\text { Provided by Worldwide Governance Indicators, this } \\
\text { indicator measures the efficiency of government and } \\
\text { its independence level from political pressure. }\end{array}$ & $\begin{array}{l}\text { La Porta et al. (2000), } \\
\text { Durnev and Kim (2005) }\end{array}$ \\
\hline \multirow{3}{*}{ Control } & Bank size & BANS & Ln $\sum$ assets & El-Chaarani (2015) \\
\hline & Liquidity ratio & LIQR & $\left(\sum\right.$ loans $) /\left(\sum\right.$ deposits $)$ & Permatasari (2020) \\
\hline & $\begin{array}{l}\text { Country's gross domestic } \\
\text { product (GDP) }\end{array}$ & GFPG & Variation percentage of GDP & El-Chaarani (2015) \\
\hline
\end{tabular}

These variables were subjected to fixed effects regressions and two-stage least squares regressions. Fixed effect models have the advantage of controlling the bias of omitted and unobservable variables. Results were first obtained from the fixed effects regressions, 
with two-stage least squares regressions performing a robustness check on the fixed effects regression results, by solving endogeneity and multicollinearity problems. The equations for the fixed effects regressions are presented as follows (with variables described in Table 1):

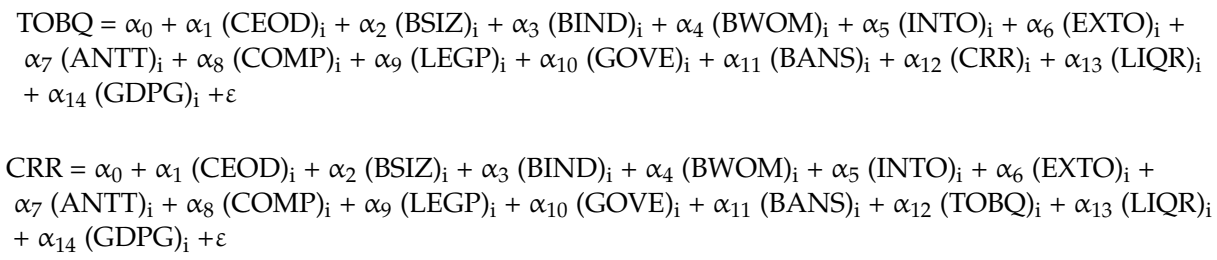

Figure 1 depicts the concurrent impact of internal and external governance mechanisms (independent variables) and control variables on bank performance and risk (dependent variables). Internal corporate governance mechanisms include CEO duality, board size, board independence, the presence of women on the board, internal ownership, external ownership, anti-takeover mechanisms, and performance-based compensation policies. External corporate governance mechanisms include legal protections, along with government effectiveness in curbing political pressure on boards. The governance mechanisms operate within a contingency framework that can influence governance effects on bank performance. Fixed control variables describing this framework include bank size, liquidity risk, and GDP growth.

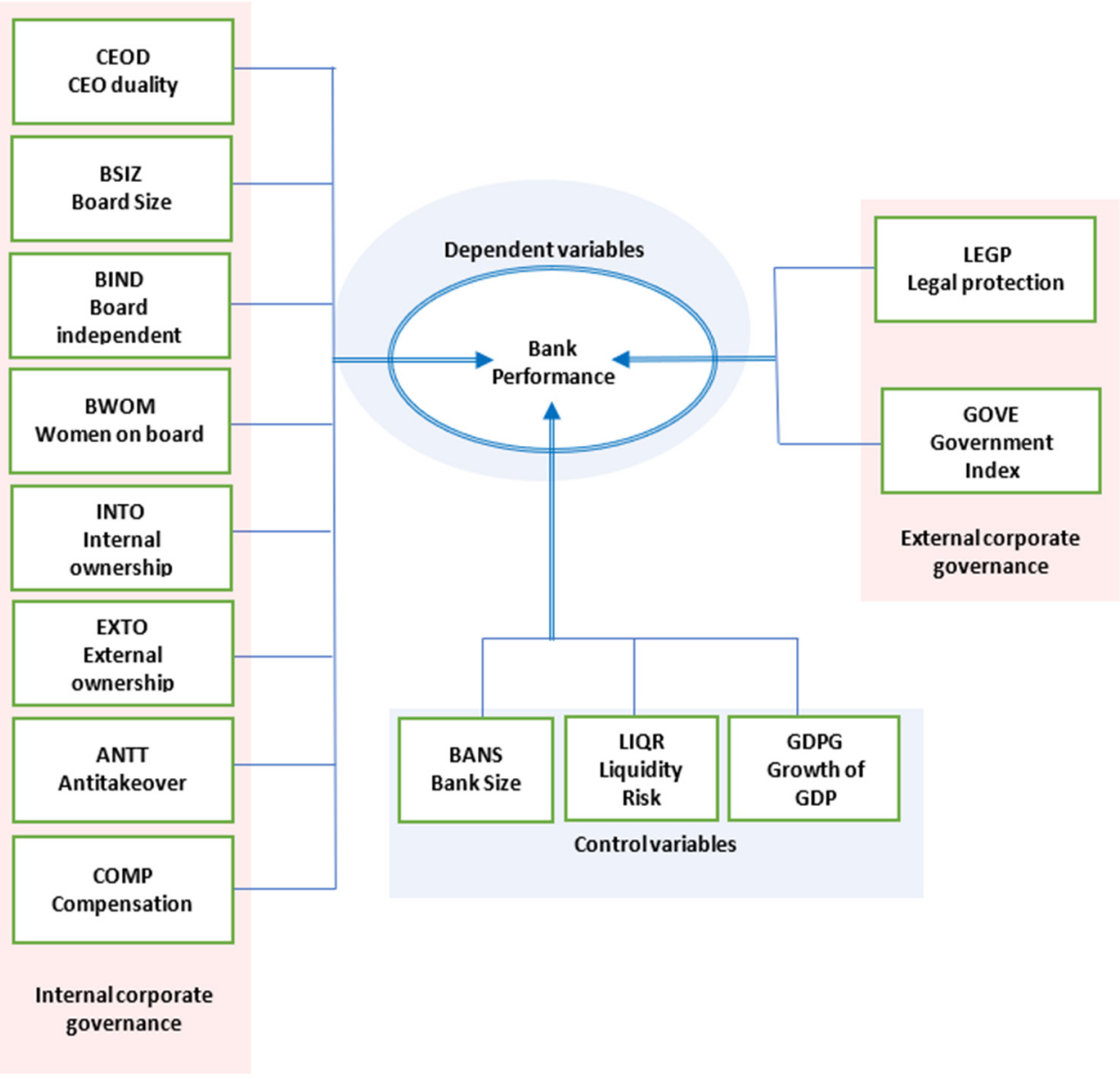

Figure 1. Research Model. 


\section{Results}

\subsection{Descriptive Statistics}

Bank Performance, Credit Risk and Liquidity Risk: Table 3 shows that all commercial banks were undervalued, since Tobin's $Q$ values were $<1$. The weakest banking sector performance was in Iran (0.9483), with the strongest being in the United Arab Emirates (0.9864). Credit risk was considered to be relatively high overall, during the pandemic period with highest levels of credit risk being measured in Iran (8.7473), Saudi Arabia (6.2876), and Egypt (6.8361). Liquidity risk was relatively low during the pandemic period since the majority of liquidity risk means were $<80 \%$. The highest levels of liquidity risk were in Qatar (85.6249) and Oman (90.9588), with the lowest level in Bahrain (64.3831).

Table 3. Financial Indicators of the Banking Sector in the MENA Region During the Pandemic.

\begin{tabular}{|c|c|c|c|c|c|c|c|c|c|}
\hline \multirow{2}{*}{ Country } & \multirow{2}{*}{$\mathbf{N}$} & \multicolumn{2}{|c|}{ Tobin's Q } & \multicolumn{2}{|c|}{ Credit Risk } & \multicolumn{2}{|c|}{ Liquidity Risk } & \multicolumn{2}{|c|}{ Bank Size } \\
\hline & & Mean & SD & Mean & SD & Mean & SD & Mean & SD \\
\hline Qatar & 12 & 0.9760 & 0.2209 & 3.3295 & 1.6122 & 85.6249 & 8.1415 & 7.5671 & 0.4774 \\
\hline Oman & 5 & 0.9726 & 0.3168 & 4.3927 & 0.9983 & 90.9588 & 12.4113 & 7.0834 & 0.2556 \\
\hline Bahrain & 10 & 0.9651 & 0.3844 & 4.8676 & 1.5632 & 64.3831 & 6.7373 & 7.0137 & 0.5751 \\
\hline Saudi Arabia & 10 & 0.9667 & 0.2224 & 6.2876 & 1.5004 & 75.9626 & 7.8653 & 7.8155 & 0.2323 \\
\hline Egypt & 25 & 0.9701 & 0.4681 & 6.5361 & 1.1293 & 65.3902 & 5.3932 & 7.3009 & 0.4032 \\
\hline Kuwait & 9 & 0.9825 & 0.3203 & 3.1445 & 1.1624 & 76.3588 & 5.0676 & 7.4055 & 0.3016 \\
\hline Jordan & 14 & 0.9732 & 0.3393 & 5.3631 & 1.3831 & 80.6472 & 4.9372 & 7.0484 & 0.2484 \\
\hline Morocco & 12 & 0.9674 & 0.4881 & 4.5921 & 1.3197 & 77.8464 & 4.8467 & 7.0937 & 0.6458 \\
\hline United Arab Emirates & 19 & 0.9864 & 0.4448 & 6.5753 & 4.3251 & 75.6252 & 9.5872 & 7.2575 & 0.7756 \\
\hline Tunisia & 20 & 0.9512 & 0.3927 & 5.2104 & 0.9363 & 78.4827 & 8.3903 & 7.0281 & 0.6819 \\
\hline Israel & 12 & 0.9716 & 0.2243 & 5.6451 & 0.1391 & 78.3414 & 5.4232 & 7.3021 & 0.3545 \\
\hline Iran & 10 & 0.9483 & 0.4204 & 8.7473 & 1.2145 & 75.0412 & 4.3501 & 7.1405 & 0.2141 \\
\hline Average in MENA & 158 & 0.9692 & 0.3535 & 5.3329 & 1.4403 & 77.0554 & 6.9292 & 7.2547 & 0.4304 \\
\hline
\end{tabular}

Board Size: The average board size in the banking sector was 10.097 (see Table 4). Bahraini banks had the largest average board size (13.819), whereas banks in Jordan had the lowest average board size. The presence of independent directors and women on boards was very low (0.3201 and 0.127 , respectively). The low level of independent directors suggests that the level of CEO duality would be relatively high (0.4171).

Ownership Concentration, Anti-takeover Mechanisms, and Performance-Based Compensation: Banks in the MENA region were mainly controlled by insiders, since the average of both internal and external ownership concentration was 0.4358 and 0.1764 , respectively. Banks in Qatar had the highest level of internal ownership (0.553), while banks in Israel had the lowest level of internal ownership concentration (0.346). North African banks had a greater tendency to employ anti-takeover mechanisms, as banks in Egypt and Morocco employed, on average, more than five anti-takeover devices. Few banks in MENA countries use the compensation plan as an internal corporate governance mechanism, as only $29.99 \%$ of banks employed performance-based compensation plans.

Legal Protection and Independence from Political Pressure: The efficiency of external corporate governance mechanisms is extremely weak in the MENA region. Table 5 indicates that the average means of legal protection and government oversight indicators were 0.2008 and 0.1880 , respectively. Iran and Egypt had the lowest level of external governance indicators. On the other hand, Israel and the United Arab Emirates have optimally efficient external governance indicators. 
Table 4. Internal Corporate Governance Indicators.

\begin{tabular}{|c|c|c|c|c|c|c|c|c|c|c|c|c|c|c|c|c|c|}
\hline \multirow{2}{*}{ Country } & \multirow[t]{2}{*}{$\mathbf{N}$} & \multicolumn{2}{|c|}{ Board Size } & \multicolumn{2}{|c|}{$\begin{array}{l}\text { Independents } \\
\text { on Board }\end{array}$} & \multicolumn{2}{|c|}{ CEO Duality } & \multicolumn{2}{|c|}{$\begin{array}{c}\text { Women on } \\
\text { Board }\end{array}$} & \multicolumn{2}{|c|}{$\begin{array}{l}\text { Internal } \\
\text { Ownership }\end{array}$} & \multicolumn{2}{|c|}{$\begin{array}{c}\text { External } \\
\text { Ownership }\end{array}$} & \multicolumn{2}{|c|}{ Anti-Takeover } & \multicolumn{2}{|c|}{$\begin{array}{c}\text { Compensation } \\
\text { Plan }\end{array}$} \\
\hline & & Mean & SD & Mean & SD & Mean & SD & Mean & SD & Mean & SD & Mean & SD & Mean & SD & Mean & SD \\
\hline Qatar & 12 & 9.423 & 1.335 & 0.423 & 0.089 & 0.451 & 0.056 & 0.144 & 0.039 & 0.553 & 0.146 & 0.185 & 0.089 & 3.089 & 1.551 & 0.431 & 0.139 \\
\hline Oman & 5 & 9.622 & 2.013 & 0.204 & 0.145 & 0.362 & 0.070 & 0.000 & 0.000 & 0.422 & 0.122 & 0.155 & 0.064 & 4.711 & 1.393 & 0.312 & 0.093 \\
\hline Bahrain & 10 & 13.819 & 2.494 & 0.457 & 0.117 & 0.255 & 0.054 & 0.184 & 0.042 & 0.371 & 0.094 & 0.194 & 0.043 & 3.705 & 1.092 & 0.404 & 0.122 \\
\hline $\begin{array}{l}\text { Saudi } \\
\text { Arabia }\end{array}$ & 10 & 11.414 & 1.848 & 0.295 & 0.089 & 0.502 & 0.081 & 0.000 & 0.000 & 0.494 & 0.115 & 0.152 & 0.035 & 3.343 & 0.948 & 0.384 & 0.106 \\
\hline Egypt & 25 & 8.528 & 2.383 & 0.209 & 0.091 & 0.510 & 0.092 & 0.185 & 0.061 & 0.386 & 0.076 & 0.145 & 0.030 & 5.292 & 0.331 & 0.221 & 0.068 \\
\hline Kuwait & 9 & 13.013 & 1.748 & 0.343 & 0.072 & 0.450 & 0.102 & 0.146 & 0.036 & 0.395 & 0.059 & 0.126 & 0.057 & 4.827 & 0.483 & 0.199 & 0.070 \\
\hline Jordan & 14 & 8.011 & 2.336 & 0.298 & 0.083 & 0.352 & 0.088 & 0.175 & 0.060 & 0.441 & 0.130 & 0.219 & 0.085 & 4.981 & 1.391 & 0.208 & 0.108 \\
\hline Morocco & 12 & 9.273 & 1.495 & 0.361 & 0.066 & 0.502 & 0.096 & 0.168 & 0.054 & 0.488 & 0.099 & 0.120 & 0.087 & 5.333 & 1.303 & 0.280 & 0.112 \\
\hline $\begin{array}{l}\text { United } \\
\text { Arab } \\
\text { Emirates }\end{array}$ & 19 & 8.713 & 2.493 & 0.431 & 0.037 & 0.234 & 0.073 & 0.187 & 0.012 & 0.396 & 0.103 & 0.286 & 0.113 & 3.058 & 1.002 & 0.217 & 0.103 \\
\hline Tunisia & 20 & 10.661 & 3.595 & 0.153 & 0.085 & 0.477 & 0.094 & 0.108 & 0.036 & 0.442 & 0.128 & 0.161 & 0.074 & 4.927 & 0.848 & 0.342 & 0.090 \\
\hline Israel & 9 & 9.841 & 2.580 & 0.399 & 0.115 & 0.369 & 0.091 & 0.194 & 0.085 & 0.346 & 0.169 & 0.271 & 0.112 & 4.982 & 1.224 & 0.327 & 0.121 \\
\hline Iran & 10 & 8.846 & 2.944 & 0.269 & 0.092 & 0.542 & 0.082 & 0.033 & 0.025 & 0.495 & 0.111 & 0.103 & 0.066 & 4.361 & 0.914 & 0.274 & 0.117 \\
\hline $\begin{array}{l}\text { Average } \\
\text { in } \\
\text { MENA }\end{array}$ & 158 & 10.097 & 2.272 & 0.3202 & 0.0901 & 0.4172 & 0.0816 & 0.1270 & 0.0375 & 0.4358 & 0.1127 & 0.1764 & 0.0713 & 4.3841 & 1.0400 & 0.2999 & 0.1041 \\
\hline
\end{tabular}

Table 5. External corporate governance indicators.

\begin{tabular}{|c|c|c|c|c|c|}
\hline \multirow{2}{*}{ Country } & \multirow{2}{*}{$\mathbf{N}$} & \multicolumn{2}{|c|}{ Legal Protection Indicator } & \multicolumn{2}{|c|}{ Government Effectiveness Indicator } \\
\hline & & Mean & SD & Mean & SD \\
\hline Qatar & 12 & 0.8511 & 0.2312 & 0.9121 & 0.2531 \\
\hline Oman & 5 & 0.4644 & 0.2566 & 0.1402 & 0.2644 \\
\hline Bahrain & 10 & 0.6326 & 0.2455 & 0.4335 & 0.2682 \\
\hline Saudi Arabia & 10 & 0.2629 & 0.2328 & 0.1583 & 0.2442 \\
\hline Egypt & 25 & -0.6978 & 0.1801 & -0.5515 & 0.2014 \\
\hline Kuwait & 9 & 0.2924 & 0.2400 & -0.1609 & 0.2668 \\
\hline Jordan & 14 & 0.2357 & 0.1902 & 0.1171 & 0.2210 \\
\hline Morocco & 12 & -0.128 & 0.18484 & -0.0392 & 0.2181 \\
\hline United Arab Emirates & 19 & 1.0866 & 0.2116 & 1.3359 & 0.2494 \\
\hline Tunisia & 20 & -0.3693 & 0.1871 & -0.2014 & 0.2094 \\
\hline Israel & 12 & 1.2413 & 0.2684 & 1.1056 & 0.2588 \\
\hline Iran & 10 & -1.4619 & 0.2199 & -0.9928 & 0.2594 \\
\hline Average in MENA & 158 & 0.2008 & 0.2206 & 0.1880 & 0.2428 \\
\hline
\end{tabular}

\subsection{Correlations}

Table 6 shows the correlation matrix. Bank performance was positively and significantly correlated with both levels of internal ownership concentration and external governance indicators. When there is a strong legal protection level, banks are more willing to increase the presence of women and independent members on the board of directors, and less willing to employ CEO-duality and anti-takeover devices. The level of ownership concentration is negatively and significatively correlated with both liquidity and credit risks. External shareholders are less willing to own bank capital when it is controlled by internal shareholders. Finally, the presence of high external ownership concentration is positively and significatively correlated with the presence of independent members and board size. 
Table 6. Correlations of Variables.

\begin{tabular}{|c|c|c|c|c|c|c|c|c|c|c|c|c|c|c|c|}
\hline & TOBQ & CEOD & BSIZ & BIND & BWOM & INTO & EXTO & ANTT & COMP & LEGP & GOVE & BANS & CRR & LIQR & GFPG \\
\hline TOBQ & 1 & & & & & & & & & & & & & & \\
\hline CEOD & -0.482 & 1 & & & & & & & & & & & & & \\
\hline BSIZ & -0.393 & -0.394 & 1 & & & & & & & & & & & & \\
\hline BIND & 0.388 & -0.231 & 0.311 & 1 & & & & & & & & & & & \\
\hline BWOM & 0.038 & 0.014 & 0.031 & 0.035 & 1 & & & & & & & & & & \\
\hline INTO & 0.411 * & 0.412 & 0.118 & -0.481 & 0.021 & 1 & & & & & & & & & \\
\hline EXTO & 0.331 & -0.119 & 0.041 * & $\underset{* *}{0.061}$ & 0.048 & $-\underset{* *}{-0.241}$ & 1 & & & & & & & & \\
\hline ANTT & 0.049 & 0.321 & 0.031 & 0.041 & -0.071 & 0.031 * & -0.395 & 1 & & & & & & & \\
\hline COMP & 0.035 & 0.031 & 0.014 & 0.035 & 0.048 & 0.042 & 0.408 & -0.024 & 1 & & & & & & \\
\hline LEGP & $0.048^{*}$ & $\underset{*}{-0.234}$ & -0.331 & $0.058 *$ & 0.131 * & 0.291 & 0.256 & $\underset{*}{-0.381}$ & 0.039 & 1 & & & & & \\
\hline GOVE & 0.073 * & $\underset{*}{-0.301}$ & -0.245 & $\underset{* *}{0.103}$ & $\underset{* *}{0.098}$ & 0.193 & 0.249 & $\begin{array}{c}-0.229 \\
*\end{array}$ & 0.042 & $\underset{* * *}{0.903}$ & 1 & & & & \\
\hline BANS & -0.302 & -0.048 & 0.204 & 0.091 & 0.039 & 0.184 & 0.102 & 0.012 & 0.181 & 0.138 & 0.094 & 1 & & & \\
\hline CRR & -0.039 & 0.024 & 0.021 & -0.073 & 0.104 & $\underset{*}{-0.294}$ & $\begin{array}{c}-0.187 \\
*\end{array}$ & 0.231 & 0.219 & -0.031 & -0.121 & 0.301 & 1 & & \\
\hline LIQR & -0.014 & 0.078 & 0.019 & -0.034 & 0.094 & $\underset{* *}{-0.318}$ & $-\underset{* *}{-0.229}$ & 0.129 & 0.159 & -0.020 & -0.109 & 0.294 & $0.294^{*}$ & 1 & \\
\hline GFPG & -0.141 & 0.023 & 0.045 & 0.006 & 0.001 & 0.218 & 0.019 & 0.003 & 0.029 & 0.002 & 0.039 & 0.032 & 0.108 & 0.045 & 1 \\
\hline
\end{tabular}

\subsection{Hypotheses Tests}

Table 7 presents the results of three fixed-effect models. Hypothesis 1 predicted the positive impact on bank performance of independent directors on the board. Hypothesis 1 was supported, as the coefficients for independent members (BIND) were positive and highly significant (1\%) in models $1,3,4$ and 6 . Their presence on the board during the pandemic period may reduce agency problems and decrease the potential expropriation of shareholders and risky lending strategy, leading to improved financial performance and decreased credit risk. Hypothesis 2 suggested that the presence of women on the board of directors would positively affect bank performance. Hypothesis 2 was rejected, as none of the six fixed effects regression models showed a significant value for BWOM, or the positive effect of women directors on the board on bank financial performance. Hypothesis 3 predicted that CEO-board duality would negatively influence bank financial performance. Table 7 indicates that CEOD, the CEO-board duality indicator, had no significant impact on bank financial performance, rejecting Hypothesis 3. Similarly, Hypothesis 4 indicated that large board size would negatively influence bank financial performance. Table 7 shows that BSIZE, or board size, had no significant impact on bank financial performance, rejecting Hypothesis 4. The results show positive and significant impacts of both internal (INTO) and external (EXTO) ownership concentration on bank performance, and absence of both variables (INTO) and (EXTO) on credit risk, partially supporting Hypotheses $5 \mathrm{a}$ and $5 b$, respectively. Furthermore, the results reveal that the impact of internal ownership concentration (INTO) on bank performance was much higher than the impact of external ownership concentration (EXTO). The development of ownership concentration during crisis periods can reduce the expropriation of private benefits and minimize risky behavior, leading to improved financial performance. Ownership concentration further reduces agency costs, by decreasing the traditional conflicts between agent and principals, as principals are sufficiently powerful to restrain unproductive agent behavior. Hypothesis 6 conjectured that anti-takeover mechanisms would adversely influence bank performance. Hypothesis 6 was rejected, as the ANTT variable measuring the use of anti-takeover mechanisms was insignificant in influencing bank performance and credit risk. Hypothesis 7 suggested that performance-based compensation would positively influence bank perfor- 
mance. However, the COMP variable in Table 7 yielded an insignificant effect on bank performance and credit risk.

Table 7. Regression Analysis-Fixed Effects Model.

\begin{tabular}{|c|c|c|c|c|c|c|c|c|c|c|c|c|}
\hline \multirow[b]{3}{*}{ Constant } & \multicolumn{6}{|c|}{ Dependent Variable: TOВQ } & \multicolumn{6}{|c|}{ Dependent Variable: CRR } \\
\hline & \multicolumn{2}{|c|}{ Model 1} & \multicolumn{2}{|c|}{ Model 2} & \multicolumn{2}{|c|}{ Model 3} & \multicolumn{2}{|c|}{ Model 4} & \multicolumn{2}{|c|}{ Model 5} & \multicolumn{2}{|c|}{ Model 6} \\
\hline & $\underset{* *}{0.76543}$ & 6.0760 & $\underset{* * *}{0.1865}$ & 3.8720 & $\underset{* * *}{0.3764}$ & 4.7018 & $\underset{* * *}{0.5903}$ & 4.0574 & $\underset{* * *}{0.2837}$ & 3.8751 & $\underset{* * *}{0.4702}$ & 5.4672 \\
\hline CEOD & -0.0938 & -2.0348 & & & -0.0563 & -2.0848 & 0.0053 & 1.7723 & & & 0.0065 & 1.8027 \\
\hline BSIZ & -0.0935 & -1.8751 & & & -0.1094 & -0.0116 & 0.0076 & 1.4367 & & & 0.0083 & 1.6802 \\
\hline BIND & $\underset{* * *}{0.2816}$ & 4.9381 & & & $\underset{* * *}{0.2741}$ & 6.2910 & $\underset{* * *}{-0.0682}$ & -3.6950 & & & -0.0701 & -3.9016 \\
\hline BWOM & 0.0481 & 0.9585 & & & 0.0516 & 1.5951 & -0.0025 & -1.0395 & & & -0.0071 & -1.1195 \\
\hline INTO & 0.1378 & 3.4184 & & & $\underset{* * *}{0.1582}$ & 5.4711 & -0.1258 & -1.2204 & & & -0.1361 & -1.3001 \\
\hline EXTO & $\underset{* * *}{0.0894}$ & 4.2296 & & & $\underset{* * *}{0.0692}$ & 5.3581 & -0.0241 & -1.2481 & & & -0.0338 & -1.4906 \\
\hline ANTT & -0.0759 & -1.6549 & & & -0.0732 & -1.5344 & 0.0595 & 0.9474 & & & 0.0572 & 0.8582 \\
\hline COMP & 0.1216 & 1.8880 & & & 0.1608 & 1.7601 & -0.0745 & 1.7751 & & & -0.0552 & 1.8621 \\
\hline LEGP & & & $\underset{* * *}{0.5098}$ & 4.8696 & $\underset{* * *}{0.5747}$ & 5.9806 & & & $\underset{* * *}{-0.2571}$ & -4.8676 & $-\underset{* * *}{0.2773}$ & -3.9619 \\
\hline GOVE & & & $\underset{* * *}{0.4106}$ & 5.6533 & $\underset{* * *}{0.4953}$ & 4.9184 & & & $\underset{* * *}{-0.3562}$ & -5.7931 & $\underset{* * *}{-0.2975}$ & -3.7062 \\
\hline BANS & $0.0390 * *$ & 2.5313 & $0.0584^{* *}$ & 2.9001 & $\underset{* * *}{0.0554}$ & 3.8474 & 0.0655 & 1.7686 & 0.0557 & 1.6503 & 0.0847 & 1.6005 \\
\hline LIQR & -0.1717 & -1.4040 & -0.2092 & -1.5529 & -0.2040 & -1.5061 & $\underset{* * *}{0.1862}$ & 3.6001 & $\underset{* * *}{0.2110}$ & 3.6771 & $\underset{* * *}{0.1968}$ & 4.8565 \\
\hline GFPG & $\underset{* * *}{0.0709}$ & 3.5951 & $\underset{* * *}{0.0864}$ & 4.3931 & $\underset{* * *}{0.0680}$ & 4.6637 & 0.0213 & 0.1856 & 0.0250 & 0.1572 & 0.0224 & 0.1684 \\
\hline CRR & -0.2831 & -0.1559 & -0.3074 & -0.3204 & -0.2405 & -0.4421 & & & & & & \\
\hline TOBQ & & & & & & & 0.1157 & 1.4723 & 0.1592 & 1.2846 & 0.0957 & 1.7752 \\
\hline $\mathrm{R}^{2}$ & \multicolumn{2}{|c|}{0.15} & \multicolumn{2}{|c|}{0.17} & \multicolumn{2}{|c|}{0.33} & \multicolumn{2}{|c|}{0.15} & \multicolumn{2}{|c|}{0.18} & \multicolumn{2}{|c|}{0.29} \\
\hline F-Statistics & \multicolumn{2}{|c|}{2.6461} & \multicolumn{2}{|c|}{3.1027} & \multicolumn{2}{|c|}{5.8938} & \multicolumn{2}{|c|}{2.6019} & \multicolumn{2}{|c|}{3.2582} & \multicolumn{2}{|c|}{4.7676} \\
\hline $\begin{array}{c}\text { Prob(F- } \\
\text { Statistic) }\end{array}$ & \multicolumn{2}{|c|}{0.0000} & \multicolumn{2}{|c|}{0.0000} & \multicolumn{2}{|c|}{0.0000} & \multicolumn{2}{|c|}{0.0000} & \multicolumn{2}{|c|}{0.0000} & \multicolumn{2}{|c|}{0.0000} \\
\hline $\begin{array}{l}\text { Durbin } \\
\text { Watson }\end{array}$ & \multicolumn{2}{|c|}{1.68} & \multicolumn{2}{|c|}{1.73} & \multicolumn{2}{|c|}{1.82} & \multicolumn{2}{|c|}{2.15} & & & & \\
\hline $\begin{array}{l}\text { Hausman } \\
\text { Test }\end{array}$ & 133.3351 & $(0.0000)$ & 128.3714 & $(0.0000)$ & 51.1641 & $(0.0000)$ & 125.5171 & $(0.0000)$ & 119.6282 & $(0.0000)$ & 67.9575 & $(0.0000)$ \\
\hline
\end{tabular}

${ }^{* *} p<0.01,{ }^{* * *} p<0.001$.

Regarding the relationship between bank performance and external corporate governance mechanisms, the results of models 2 and 3 in Table 7 show positive and significant effects of efficient government oversight and legal protection on the performance of the banking sector. Furthermore, the results of models 5 and 6 in Table 7 indicate a negative impact of efficient government and legal protection on the credit risk of banking firms in MENA region. Thus, the strengthening of financial regulation and government oversight during pandemic periods are likely to be well valued by investors which will mitigate the negative impact of any unexpected shock, supporting Hypotheses 8 and 9, respectively.

\subsection{The Effect of Control Variables on Bank Performance}

With respect to the impact of the bank size variable (BANS) on financial performance, the findings show a positive and significant effect, at the $1 \%$ threshold, in the first three models presented in Table 7. On the other hand, the results of models 4, 5 and 6 do not reveal any significant impact of bank size variable (BANS) on the credit risk. Thus, during crisis periods, large banks in the MENA region have more capacity to resist threats and increase their financial performance. Large banks have more capacity and synergy to control their operational costs and provide economies of scale. 
The financial performance of the banking sector is positively correlated to the level of GDP growth. Furthermore, this positive relationship is consistent with the study of Bermpei et al. (2018). Therefore, bank performance cannot be isolated from macroeconomic indicators. Bankers must avoid taking reckless risks because banks are highly volatile and vulnerable to the economic impact of the COVID-19 pandemic shock.

Finally, the results of models 4, 5, and 6 show that the financial liquidity risk (LIQR) is positively correlated to the level of credit risk (CRR). Thus, the excess of lending strategy increases the level of non-performing loans during crisis periods.

\subsection{Robustness Check}

The two-stage least squares (2SLS) model was employed on the same data to examine the robustness of the observed results in the fixed-effect model. The 2SLS model has the advantage of solving problems of endogeneity of independent variables, and multicollinearity.

The results of the two-stage least squares (2SLS) model presented in Table 8 show almost similar results to the fixed-effect models in Table 7 . The coefficients of the relationship between bank performance on the one hand and independent members, internal ownership concentration, external ownership concentration, legal protection indicator, and the government oversight indicators are positive and significant at the $1 \%$ threshold. The results also confirm the absence of any relationship between bank performance and CEO duality, board size, the involvement of women on the board, anti-takeover, or performance-based compensation. The results show similar effects for the control variables on the performance of the banking sector.

Table 8. Regression analysi-Two- Stage Least Squares model.

\begin{tabular}{|c|c|c|c|c|c|c|c|c|c|c|c|c|}
\hline \multirow[b]{3}{*}{ Constant } & \multicolumn{6}{|c|}{ Dependent Variable: ТОВQ } & \multicolumn{6}{|c|}{ Dependent Variable: CRR } \\
\hline & \multicolumn{2}{|c|}{ Model 1} & \multicolumn{2}{|c|}{ Model 2} & \multicolumn{2}{|c|}{ Model 3} & \multicolumn{2}{|c|}{ Model 4} & \multicolumn{2}{|c|}{ Model 5} & \multicolumn{2}{|c|}{ Model 6} \\
\hline & $\underset{* * *}{0.8171}$ & 5.2388 & $\underset{* * *}{0.1995}$ & 4.5928 & $\underset{* * *}{0.8643}$ & 6.1537 & $\underset{* * *}{0.6331}$ & 4.7215 & $\underset{* * *}{0.2018}$ & 3.4521 & $\underset{* * *}{0.5622}$ & 4.0621 \\
\hline CEOD & -0.0746 & -2.7401 & & & -0.0563 & -2.0848 & 0.0034 & 1.6722 & & & 0.0021 & 1.2572 \\
\hline BSIZ & -0.1082 & -1.3515 & & & -0.1094 & -0.0116 & 0.0057 & 1.2567 & & & 0.0083 & 1.6802 \\
\hline BIND & $\underset{* * *}{0.2816}$ & 4.9381 & & & $\underset{* * *}{0.2741}$ & 6.2910 & $-\underset{* * *}{0.0682}$ & -3.6950 & & & $-\underset{* * *}{0.0701}$ & -3.9016 \\
\hline BWOM & 0.0481 & 0.9585 & & & 0.0547 & 1.3011 & -0.0023 & -1.0329 & & & -0.0071 & -1.1195 \\
\hline INTO & $\underset{* * *}{0.1378}$ & 3.4184 & & & $\underset{* * *}{0.1511}$ & 4.3095 & -0.1236 & -1.2252 & & & -0.1361 & -1.3001 \\
\hline EXTO & $\underset{* * *}{0.0894}$ & 4.2296 & & & $\underset{* * *}{0.0692}$ & 5.3581 & -0.0241 & -1.2481 & & & -0.0338 & -1.4906 \\
\hline ANTT & -0.0759 & -1.6549 & & & -0.0732 & -1.5344 & 0.0596 & 0.9326 & & & 0.0535 & 0.8525 \\
\hline COMP & 0.1753 & 1.9865 & & & 0.1608 & 1.7601 & -0.0745 & 1.7751 & & & -0.0552 & 1.8621 \\
\hline LEGP & & & $\underset{* * *}{0.4374}$ & 6.3684 & $\underset{* * *}{0.5747}$ & 5.9806 & & & -0.2571 & -4.8676 & -0.2773 & -3.9619 \\
\hline GOVE & & & $\underset{* * *}{0.4106}$ & 5.6533 & $\underset{* * *}{0.4953}$ & 4.9184 & & & $-\underset{* * *}{-0.3562}$ & -5.7931 & $-\underset{* * *}{0.2975}$ & -3.7062 \\
\hline BANS & $0.0400 * *$ & 2.6118 & $0.0584^{* *}$ & 2.9001 & $\underset{* * *}{0.0554}$ & 3.8474 & 0.0646 & 1.5687 & 0.0657 & 1.4503 & 0.0647 & 1.7005 \\
\hline LIQR & -0.1717 & -1.4040 & -0.2092 & -1.5529 & -0.2040 & -1.5062 & $\underset{* * *}{0.1861}$ & 3.6022 & $\underset{* * *}{0.2110}$ & 3.6771 & $\underset{* * *}{0.1968}$ & 4.8565 \\
\hline GFPG & $\underset{* * *}{0.0709}$ & 3.5951 & $\underset{* * *}{0.0864}$ & 5.0018 & $\underset{* * *}{0.0680}$ & 4.6637 & 0.0215 & 0.1841 & 0.0251 & 0.1542 & 0.0252 & 0.1661 \\
\hline CRR & 0.2831 & -0.1559 & -0.3074 & -0.3204 & -0.2405 & -0.4421 & & & & & & \\
\hline TOBQ & & & & & & & 0.1157 & 1.4723 & 0.1592 & 1.2846 & 0.0944 & 1.7731 \\
\hline $\mathrm{R}^{2}$ & \multicolumn{2}{|c|}{0.15} & \multicolumn{2}{|c|}{0.16} & \multicolumn{2}{|c|}{0.31} & \multicolumn{2}{|c|}{0.21} & \multicolumn{2}{|c|}{0.32} & \multicolumn{2}{|c|}{0.28} \\
\hline F-Statistics & \multicolumn{2}{|c|}{2.5409} & \multicolumn{2}{|c|}{3.5204} & \multicolumn{2}{|c|}{5.3851} & \multicolumn{2}{|c|}{3.1035} & \multicolumn{2}{|c|}{3.4804} & \multicolumn{2}{|c|}{4.9867} \\
\hline
\end{tabular}


Table 8. Cont.

\begin{tabular}{|c|c|c|c|c|c|c|}
\hline & \multicolumn{3}{|c|}{ Dependent Variable: TOBQ } & \multicolumn{3}{|c|}{ Dependent Variable: CRR } \\
\hline & Model 1 & Model 2 & Model 3 & Model 4 & Model 5 & Model 6 \\
\hline $\begin{array}{l}\text { Prob(F- } \\
\text { Statistic) }\end{array}$ & 0.0000 & 0.0000 & 0.0000 & 0.0000 & 0.0000 & 0.0000 \\
\hline $\begin{array}{l}\text { Durbin } \\
\text { Watson }\end{array}$ & 1.69 & 1.74 & 1.83 & 2.18 & 2.27 & 3.02 \\
\hline $\begin{array}{c}\text { Prob(J- } \\
\text { statistic) }\end{array}$ & 0.9383 & 0.5202 & 0.1600 & 0.7562 & 0.6731 & 0.1356 \\
\hline
\end{tabular}

Furthermore, the results of the relationship between bank credit risk and all the independent variables and the control variable are almost the same. The results confirm the negative impact of the presence of independents on the board of directors, efficient legal protection indicator and government oversight on the credit risk of banking firms in the MENA region. The relationships between credit risk, on the one hand, and board size, CEO duality, women on board, ownership concentration, antitakeover and performance-based compensation are insignificant. Finally, the results in Table 8 show the same effect of the control variables on the credit risk of banking firms.

\section{Conclusions}

\subsection{Discussion of Results}

The presence of managers who were shareholders, and institutional investors, were found to positively influence bank performance during the pandemic. Each of these entities was successful in curbing adverse agency and entrenchment effects on bank performance. Independent directors performed impartial evaluations of management's performance and risk during the pandemic, as they were not bank employees. Certain managers were self-serving in rewarding themselves at the expense of the bank (agency behavior) or were so risk-averse that they would not seek alternative sources of revenue with the elimination of traditional revenue sources (entrenchment theory). Negative evaluations of such managers may have stimulated them to disengage from such behavior, and act as stewards of the bank. As stewards, they would feel personally responsible for steering the bank to profitability during the crisis, by maintaining liquidity, and finding revenue sources. Stewardship may be notable among managers who were personally invested in the bank as large shareholders, as in Qatar, Morocco, Oman, and Iran. In safeguarding the interests of the bank's other shareholders, they were essentially safeguarding their own interests, i.e., obtaining high returns for their own stock. Resource dependence theory prevailed in board relationships with institutional investors. Institutional investors, along with other large shareholders in the MENA region, may be owners of oil wealth or owners of large businesses. They maintained close relationships with the boards of banks. They had access to financial resources, and the expertise of specialists, which could assist the bank in meeting liquidity decreases, and credit risk increases, during the pandemic. Their knowledge of regulation, and the ability to provide access to key government agents, including central bankers, government regulatory board members, and influential business owners, may have exposed management and board members to novel strategies for building revenue, and maintaining cash reserves. The finding that large banks positively influence financial performance supports the above position that large banks, with institutional investors and large shareholders, were in a position to undertake the liquidity enhancement, and credit risk reduction caused by the pandemic. These conditions may have prevailed in the United Arab Emirates, Israel, and Jordan, which had the highest levels of external ownership concentration.

Freedom of decision-making among board members can only occur in an environment in which there are no repercussions for innovative thinking, and impartial evaluation of management. Such an environment exists in Israel, and the United Arab Emirates. Therefore, the presence of strong legal protection for the board, along with public institutions 
that promote plurality, will be effective in resisting political pressure to restrict bank board independence.

A growing economy with rising GDP provided the economic environment in which board independence thrived during a pandemic, as prosperity is needed for the bank to continue to make business and personal loans, issue credit cards, issue mortgages, and make automobile loans. Further, experimentation with novel financial products assumes a growing economy that can purchase these products, while sustaining them throughout the crises. As an example, special credit cards may be targeted to owners of online businesses. The bank had to rely on phone calls, and social media advertising during the pandemic, while, in the past, it used face-to-face interaction. The marketing staff benefitted from consultation with experts in digital marketing, and telephone communication, who may only be found in growing economies, which regularly need their services.

\subsection{Practical and Theoretical Implications of Research}

This research contributes to academic study and supports practitioners in various ways. First, few empirical research papers exist on the impact of corporate governance on the performance of banking firms during the COVID-19 pandemic period. Thus, this research enriches the limited literature on the corporate governance in the COVID-19 era. Second, this paper employs agency theory and entrenchment theory to provide new foundations for identifying corporate governance mechanisms affecting the performance of banking firms during crisis periods. In line with agency theory, the results confirmed that independent members and ownership concentration are important factors that could mitigate the negative impact of crisis periods. Third, the results revealed in this research have important implications for bankers, investors and financial regulators. The findings of this paper will be useful for financial authorities and shareholder who are looking to minimize any inappropriate behavior that could be initiated by managers and CEOs during a crisis. In this context, financial authorities and bankers in the Middle East region are expected to reinforce their corporate governance practices to prepare the banking sector to face any crisis, while considering their stakeholders needs.

\subsection{Limitations and Extended Research Projects}

First, this paper studied the impact of corporate governance on the performance of banks for just one year (2020). Second, the bank year observations were very limited, with only 158 banks examined. Third, this research did not consider many macroeconomic factors, such as oil prices, since it is well-known that the majority of MENA countries are oil producers and exporters. Fourth, this paper sheds light on quantitative dimensions of corporate governance variables but does not consider several corporate governance factors that could affect the performance of banking firms. Fifth, Tobin's $Q$ was considered to measure the performance of the banking sector, while return on assets (ROA), return on equity (ROE), market risk, and credit risk may provide additional information. In light of these limitations, the study could be extended. The performance of the banking sector could be measured using return on assets (ROA), return on equity (ROE) and total assets to total deposits ratio (TA/TD). The sample size could be developed to include more banks and the period of study extended over additional years. Key rates on loans defined by central and commercial banks, oil prices, inflation, and compensation value could be included. Other statistical methods, such as GMM and PSCE, could be used to test the consistency and endogeneity of the observed results. Finally, future research could compare the preand post-COVID-19 pandemic periods.

Author Contributions: Conceptualization, H.E.-C.; methodology, H.E.-C.; software, H.E.-C. and Y.S.; validation, H.E.-C.; writing, review, and editing, H.E.-C. and R.A.; visualization, R.A.; supervision, H.E.-C.; project administration, Y.S. We confirm that neither the manuscript, nor any parts of its content are currently under consideration or published in another journal. All authors have read and agreed to the published version of the manuscript. 
Funding: This research received no external funding.

Data Availability Statement: Data is available upon request.

Conflicts of Interest: The authors declare no conflict of interest.

\section{References}

Abhijith, Anand, and Samuel Fosso Wamba. 2013. Business Value of RFID-enabled healthcare transformation projects. Business Process Management Journal 19: 111-45. [CrossRef]

Adnan, Muhammad Akhyar, Sheila Nu Nu Htay, Hafiz Majdi Ab Rashid, and Ahamed Kameel Mydin Meera. 2011. A panel data analysis on the relationship between corporate governance and bank efficiency. Journal of Accounting, Finance and Economics 1: $1-15$.

Akhtaruzzaman, Md, Sabri Boubaker, and Zaghum Umar. 2021. COVID-19 media coverage and ESG leader indices. Finance Research Letters 25: 102-70. [CrossRef]

Al Dah, Bilal, Amir Michael, and Rob Dixon. 2017. Antitakeover Provisions and CEO Monetary Benefits: Revisiting the E-Index. Research in International Business and Finance 42: 992-1004. [CrossRef]

Alchian, Armen A., and Harold Demsetz. 1972. Production, information costs and economic organisation. The American Economic Revie 62: 777-95.

Amore, Mario Daniele, Valerio Pelucco, and Fabio Quarato. 2020. Family ownership during the COVID-19 pandemic. SSRN Electronic Journal 147: 1-10. Available online: https:/ / ssrn.com/abstract=3603991 (accessed on 31 January 2021). [CrossRef]

Anand, Amber, Paul Irvine, Andy Puckett, and Kumar Venkataraman. 2013. Institutional trading and stock resiliency: Evidence from the 2007-2009 financial crisis. Journal of Financial Economics 108: 773-97. [CrossRef]

Arora, Punit. 2018. Financially linked independent directors and bankruptcy reemergence: The role of director effort. Journal of Management 44: 2665-89. [CrossRef]

Baek, Jae-Seung, Jun-Koo Kang, and Kyung Suh Park. 2004. Corporate governance and firm value: Evidence from the Korean financial crisis. Journal of Financial Economics 71: 265-313. [CrossRef]

Barth, James R., Gerard Caprio Jr., and Ross Levine. 2000. Banking Systems around the Globe: Do Regulation and Ownership Affect Performance and Stability? Policy Research Working Paper 2325. Washington, DC: World Bank.

Basel Committee. 2015. Guidelines Corporate governance principles for banks. In Bank for International Settlements. Basel: Basel Committee. Available online: https:/ / bis.org (accessed on 17 December 2021).

Bebchuk, Lucian A., and Michael S. Weisbach. 2010. The state of corporate governance research. The Review of Financial Studies 23: 939-61. [CrossRef]

Bebchuk, Lucian A., John C. Coates Iv, and Guhan Subramanian. 2002. The powerful antitakeover force of staggered boards: Theory, evidence, and policy. Stanford Law Review 54: 887-951. [CrossRef]

Bebchuk, Lucian, Alma Cohen, and Allen Ferrell. 2009. What matters in corporate governance. Review of Financial Studies 22: 783-827. [CrossRef]

Beck, Thorsten, Asli Demirgüç-Kunt, and Ross Levine. 2003. Law and Finance: Why Does Legal Origin Matter? Journal of Comparative Economics 31: 65-675. [CrossRef]

Bermpei, Theodora, Antonios Kalyvas, and Thanh Cong Nguyen. 2018. Does institutional quality condition the effect of bank regulations and supervision on bank stability? Evidence from emerging and developing economies. International Review of Financial Analysis 59: 255-75. [CrossRef]

Bhattrai, Himal. 2017. Effect of corporate governance on financial performance of bank in Nepal. International Journal of Multidisciplinary Research 7: 97-110.

Black, Bernard S., Hasung Jang, and Woochan Kim. 2016. Does Corporate Governance Affect Firm Value? Evidence From Korea. Journal of Law Economics and Organization 22: 366-413. [CrossRef]

Brammer, Stephen, and Stephen Pavelin. 2008. Factors influencing the quality of corporate environmental disclosure. Business Strategy and the Environment 17: 120-36. [CrossRef]

Broadstock, David C., Kalok Chan, Louis T. W. Cheng, and Xiaowei Wang. 2021. The role of ESG performance during times of financial crisis: Evidence from COVID-19 in China. Finance Research Letters 38: 101716. [CrossRef]

Brusov, Peter, Tatiana Filatova, Natali Orekhova, Veniamin Kulik, Irwin Weil, and Andrey Brailov. 2018. The Impact of the Central Bank Key Rate and Commercial Banks Credit Rates on Creating and Maintaining of a Favorable Investment Climate in the Country. Journal of Reviews on Global Economics 7: 360-76. [CrossRef]

Buallay, Amina. 2019. Is sustainability reporting (ESG) associated with performance? Evidence from the European banking sector. Management of Environmental Quality: An International Journal 30: 98-115. [CrossRef]

Chang, Jinho, Young Jun Cho, and Hyun-Han Shin. 2007. The change in corporate transparency of Korean firms after the Asian financial crisis: An analysis using analysts' forecast data. Corporate Governance: An International Review 15: 1144-67. [CrossRef]

Chenini, Hajer, and Jarboui Anis. 2018. Analysis of the Impact of Governance on Bank Performance: Case of Commercial Tunisian Banks. Journal of the Knowledge Economy 9: 871-95.

Claessens, Stijn, Simeon Djankov, and Larry H. P. Lang. 2000. The Separation of Ownership and Control in East Asian Corporations. Journal of Financial Economics 58: 81-112. [CrossRef] 
Daily, Catherine M., Dan R. Dalton, and Albert A. Cannella Jr. 2003. Corporate governance: Decades of dialogue and data. Academy of Management Review 28: 371-82. [CrossRef]

Davis, Gerald F., and J. Adam Cobb. 2010. Resource dependence theory: Past and future. Research in the Sociology of Organizations 28: 21-42.

Davis, James H., F. David Schoorman, and Lex Donaldson. 1997. Toward a stewardship theory of management. Academy of Management Review 22: 20-47. [CrossRef]

de Haan, Jakob, Choudhry Tanveer Shehzad, and Bert Scholtens. 2010. The impact of bank ownership concentration on impaired loans and capital adequacy. Journal of Banking and Finance 34: 399-408.

Demir, Ender, and Gamze Ozturk Danisman. 2021. Banking sector reactions to COVID-19: The role of bank-specific factors and government policy responses. Research in International Business and Finance 58: 101508. [CrossRef]

Durnev, Art, and E. Han Kim. 2005. To steal or not to steal: Firm attributes, legal environment, and valuation. The Journal of Finance 60: 1461-93. [CrossRef]

El-Chaarani, Hani. 2015. The impact of financial and legal structures on the performance of European listed firms. The International Journal of Business and Finance Research 9: 39-52.

European Commission. 2008. Overview of the Links between Corporate Social Responsibility and Competitiveness. European Competitiveness Report. Brussels: European Commission, pp. 106-21.

Fahlenbrach, Rüdiger, and René M. Stulz. 2011. Bank CEO incentives and the credit crisis. Journal of Financial Economics 99: 11-26. [CrossRef]

Freeman, R. Edward. 1984. Strategic Management: A Stakeholder Approach. Boston: Pitman.

García-Meca, Emma, Isabel-María García-Sánchez, and Jennifer Martínez-Ferrero. 2015. Board diversity and its effects on bank performance: An international analysis. Journal of Banking and Finance 53: 202-14.

Georgantopoulos, Andreas G., and John Filos. 2017. Corporate governance mechanisms and bank performance: Evidence from the Greek banks during crisis period. Investment, Management and Financial Innovations 14: 160-72. [CrossRef]

Ghazali, Syamni, and Said Musnadi. 2017. The Prime Lending Rate and Profitability of Regional Banks in Indonesia. Advanced Science Letters 23: 8044-46.

Gompers, Paul, Joy Ishii, Andrew Metrick, and Joy Ishii. 2003. Corporate governance and equity prices. Quarterly Journal of Economics 118: 107-56. [CrossRef]

Goodell, John W. 2020. COVID-19 and finance: Agendas for future research. Finance Research Letters 35: 101512. [CrossRef]

Handriani, Eka, and Robiyanto Robiyanto. 2019. Institutional ownership, independent board, board size, and firm performance: Evidence from Indonesia. Contaduría y Administración 64: 1-16. [CrossRef]

Hays-Thomas, Rosemary. 2004. Why now? The Contemporary Focus on Managing Diversity. In The Psychology and Management of Workplace Diversity. Edited by Margaret S. Stockdale and Faye J. Crosby. Malden: Blackwell, pp. 3-30.

Hodgson, Allan. 2015. Management Entrenchment, Corporate governance, and Accounting Arbitrage. Pdf Retrieved 12/18/2021. Available online: http:/ / citeseerx.ist.psu.edu/viewdoc/download?doi=10.1.1.175.6265\&rep=rep1\&type=pdf $($ accessed on 1 December 2021).

Jebran, Khalil, and Shihua Chen. 2020. Can we learn lessons from the past? COVID-19 crisis and corporate governance responses. International Journal of Finance and Economics 2020: 1-9. [CrossRef]

Jensen, Michael C., and William H. Meckling. 1976. Theory of the firm: Managerial behavior, agency costs and ownership structure. Journal of Financial Economics 3: 305-60. [CrossRef]

Kabigting, Leila C. 2011. Corporate governance among banks listed in the Philippine Stock Exchange. Journal of International Business Research 10: 59.

Kaur, Manmeet, Kunjana Malik, and Sakshi Sharma. 2021. A note on boardroom challenge, board effectiveness, and corporate stewardship during COVID-19. Vision 25: 131-35. [CrossRef]

Khatib, Saleh F. A., and Abdul-Naser Ibrahim Nour. 2021. The impact of corporate governance on firm performance during the COVID-19 pandemic: Evidence from Malaysia. Journal of Asian Finance, Economics and Business 8: $0943-0952$.

Klapper, Leora F., and Inessa Love. 2002. Corporate Governance, Investor Protection, and Performance in Emerging Markets. Policy Research Working Paper 2818. Washington, DC: Mondial Bank.

Koutoupis, Andreas, Panagiotis Kyriakogkonas, Michail Pazarskis, and Leonidas Davidopoulos. 2021. Corporate governance and COVID-19: A literature review. Corporate Governance International Journal of Business in Society 2: 969-82. [CrossRef]

Kozak, Sylwester. 2021. The Impact of COVID-19 on Bank Equity and Performance: The Case of Central Eastern South European Countries. Sustainability 13: 11036. [CrossRef]

Kutan, Ali M., Nahla Samargandi, and Kazi Sohag. 2017. Does institutional quality matter for financial development and growth? Further evidence from MENA countries. Australian Economic Paper 56: 228-48. [CrossRef]

La Porta, Rafael, Florencio Lopez-de-Silanes, Andrei Shleifer, and Robert Vishny. 2000. Investor protection and corporate governance. Journal of Financial Economics 58: 3-27. [CrossRef]

Lagasio, Valentina. 2018. Corporate governance in banks: Systematic literature review and meta-analysis. Corporate Ownership $\mathcal{E}$ Control 16: 113-26.

Lamichhane, Pitambar. 2018. Corporate governance and financial performance in Nepal. NCC Journal 3: 108-20. [CrossRef] 
Lehn, Kenneth M., and Mengxin Zhao. 2006. CEO turnover after acquisitions: Are bad bidders fired? Journal of Finance 61: $1759-811$. [CrossRef]

Mertzanis, Charilaos, Mohamed A. K. Basuony, and Ehab K. A. Mohamed. 2019. Social institutions, corporate governance and firm-performance in the MENA region. Research in International Business and Finance 48: 75-96. [CrossRef]

Miralles-Quirós, María Mar, José Luis Miralles-Quirós, and Jesús Redondo Hernández. 2019. ESG performance and shareholder value creation in the banking industry: International differences. Sustainability 11: 1404. [CrossRef]

Mitchell, Ronald K., Bradley R. Agle, and Donna J. Wood. 1997. Toward a theory of stakeholder identification ans salience: Defining who and what really counts. The Academy of Management Review 22: 853-86. [CrossRef]

Nguyen, Thi Dieu Chi, Huu Nghi Phan, Hung Son Le, Thi Thuy Trang Nguyen, and Aleksandr Petrov. 2020. Corporate governance and bank performance: A case of the Vietnam banking sector. Journal of Security and Sustainability Issues 10: 63-75. [CrossRef]

Noreen, Shama, Asia Liaqat, and Fozia Parveen. 2018. Interest Rate Changes and its Impact on the Profitability of Pakistani Commercial Banks. International Journal of Academic Research in Business and Social Sciences 8: 948-54. [CrossRef]

OECD. 2017. Corporate Governance Factbook. Rome: OECD Publications.

Pathan, Shams, and Robert Faff. 2012. Does board structure in banks really affect their performance? Journal of Banking and Finance 37: 1573-89. [CrossRef]

Permatasari, Ika. 2020. Does corporate governance affect bank risk management? Case study of Indonesian banks. International Trade, Politics and Development 4: 127-39. [CrossRef]

Scherer, Andreas Georg, and Christian Voegtlin. 2020. Corporate governance for responsible innovation: Approaches to corporate governance and their implications for sustainable development. Academy of Management Perspectives 34: 182-208. [CrossRef]

Sivaprasad, Sheeja, and Sudha Mathew. 2021. Corporate governance practices and the pandemic crisis: UK evidence. Corporate Governance 21: 983-96. [CrossRef]

Song, Hyoung Ju, Jihwan Yeon, and Seoki Lee. 2020. Impact of the COVID-19 pandemic: Evidence from the U.S. restaurant industry. International Journal of Hospitality Management 92: 102702. [CrossRef]

Takahashi, Hidenori, and Kazuo Yamada. 2021. When the Japanese stock market meets COVID-19: Impact of ownership, China and US exposure, and ESG channels. International Review of Financial Analysis 74: 101670. [CrossRef]

Vicnente-Ramos, Wagner, Keythi Reymundo, Lizbbet Pari, Neisha Rudas, and Pedro Rodriguez. 2020. The effect of good corporate governance on banking profitability. Management Science Letters 10: 2045-52. [CrossRef]

Westman, Hanna. 2011. The impact of management and board ownership on profitability in banks with different strategies. Journal of Banking and Finance 35: 3300-18. [CrossRef]

Westphal, James D., and Laurie P. Milton. 2000. How experience and network ties affect the influence of demographic minorities on corporate boards. Administrative Science Quarterly 45: 366-417. [CrossRef] 